\title{
KECERNAAN LEMAK DAN SERAT KASAR PAKAN ANAK KUDA PACU (YEARLING) INDONESIA YANG DIBERI PAKAN PENGUAT LOKAL DAN IMPOR
}

\author{
Kristian Mamahit., Y.L.R Tulung., C. A. Rahasia dan S. A. E Moningkey \\ Fakultas Peternakan Universitas Sam Ratulangi Manado 95115
}

\begin{abstract}
ABSTRAK
Penelitian ini bertujuan untuk mengetahui kemampuan anak kuda pacu dalam mencerna pakan baik pakan lokal dan pakan impor. Penelitian ini dilaksanakan di Desa Tonsewer Kecamatan Tompaso selama 30 hari terdiri dari persiapan dan pengumpulan data. Data yang dikumpulkan yaitu jenis dan jumlah pakan yang diberikan pada anak kuda pacu serta jumlah feses $\left(\right.$ ekor $^{-1}$ hari $^{-1}$ ). Ternak yang digunakan berjumlah 20 ekor berumur 13-24 bulan, dimana 10 anak kuda pacu mengkonsumsi pakan lokal dan 10 anak kuda pacu mengkonsumsi pakan impor. Variabel yang diukur adalah kecernaan lemak kasar dan serat kasar yaitu selisih antara zat pakan yang dikonsumsi dengan yang diekskresikan dan dibagi dengan yang dikonsumsi di kali $100 \%$. Hasil penelitian menunjukkan bahwa rataan kecernaan lemak kasar untuk pakan lokal $66.16 \%$ dan pakan impor $75.16 \%$ sedangkan kecernaan serat kasar pakan lokal dan impor yaitu $65.53 \%$ dan $72.16 \%$. Berdasarkan analisis statistik dengan menggunakan ujit ( $t$ test) menunjukkan bahwa kecernaan lemak dan serat kasar pakan impor berbeda nyata lebih tinggi $(\mathrm{P}<0.05)$ dibandingkan dengan pakan lokal.

Kesimpulan dari penelitian ini adalah kecernaan lemak kasar dan serat kasar pakan impor lebih baik dibandingkan dengan pakan lokal.
\end{abstract}

Kata kunci : Kecernaan, lemak, serat kasar

*Korespondensi Corresponding author) : Email: tulungyohannis@gmail.com

ABSTRACT

$\begin{array}{lrr}\text { CRUDE } & \text { FIBER AND } & \text { FAT } \\ \text { DIGESTIBILITY } & \text { OF INDONESIAN } \\ \text { YEARLING } & \text { LOCAL-RACING } \\ \text { HORSE FED } & \text { LOCAL r } & \text { AND } \\ \text { IMPORTED CONCENTRATE. The }\end{array}$

objective of this study was to determine the ability of racing foals to digest feed both local and imported feed. This study was conducted at the Tonsewer Village, Tompaso District for 30 days consisting of preparation and data collection. The data were collected from type and amount of feed consumed by racing foals and the number of feces (head-1 day-1). The animals of 20 individuals at the ages of 1324 months old were used in this study. The amount of 10 racing foals were fed local feed and the rests of 10 racing foals were fed imported feed. The variables measured were digestibility of crude fat and crude fiber, found as the difference between the feed substances consumed and those excreted in feces and divided by those consumed feed at $100 \%$. The results showed that the average digestibility of crude fat for local feed was $66.16 \%$ and imported feed was $75.16 \%$, respectively. The digestibility of local and imported raw fiber feed was $65.53 \%$ and $72.16 \%$, respectively. Based on statistical analysis using the t-test showed that the digestibility of crude fiber and fat of imported feed was significantly different ( $\mathrm{P}<0.05)$ compared to local feed. This might be due to higher content of the crude 
fat and crude fiber of imported feed than those of local feed.

Keywords: Digestibility, fat, crude fiber Racing horses, local feed, imported feed.

\section{PENDAHULUAN}

Pemeliharaan kuda pacu di Indonesia termasuk manajemen pemberian pakan di Indonesia sebagian besar masih mengacu pada pemberian pakan yang dilakukan oleh negara-negara maju, dan hal ini disebabkan karena para peternak kuda lebih mengadalkan pemberian bahan baku pakan impor (Tulung, 2012). Gabah merupakan pakan lokal yang sering diganti dengan pakan impor oats pada saat menjelang pacuan, jika dilihat sekilas gabah dan oats memiliki karakteristik fisik yang sama. Namun pakan impor yang dikonsumsi kuda pacu Minahasa mengandung nilai kecernaan yang nyata lebih tinggi dibandingkan dengan pakan lokal. Hal ini disebabkan karena kualitas (sifat fisik) dari pakan impor masih lebih baik dari pakan lokal (Pongoh et al., 2015). Tujuan pemberian pakan pada ternak kuda yaitu untuk membentuk postur tubuh yang ideal sehingga dapat mencapai prestasi yang baik pada saat pacuan, faktor - faktor harus perhatikan ini oleh peternak salah satu yaitu zat-zat makanan yang terkandung dalam pakan yang diberikan.
Lemak merupakan salah satu zat makanan yang penting untuk ternak karena lemak dibutuhkan sebagai cadangan energi untuk tubuh. Lemak dalam pakan diperlukan untuk memasok energi pada kinerja tambahan dan itu tidak disimpan sebagai lemak tubuh. Ketika kuda diberi pakan tambahan berupa lemak dalam dietnya maka konsumsinya akan berkurang. Karbohidrat makanan terdapat dua bentuk yaitu serat kasar dan bahan ekstrak tanpa nitrogen, serat kasar tinggi terkandung dalam pakan hijauan dan limbah hasil pertanian, seperti jerami padi. Serat kasar pada mulanya diduga memberikan gambaran tentang bagian makanan yang tidak dapat dicerna, tetapi sebagian dapat dicerna oleh ternak ruminansia. Hal ini di karenakan komponen terbesar dari serat kasar adalah berupa dinding sel yang terdiri dari selulosa, hemiselulosa, dan lignin (Susanti dan Marhaeniyanto, 2007). Kemampuan ternak kuda untuk mencerna serat kasar sekitar 30\% dari selulosa dalam pakan. Hindgut adalah tempat utama aktivitas mikrobial dalam alat pencernaan kuda. Kecernaan zat-zat makanan merupakan faktor yang sangat menentukan kualitas bahan pakan atau ransum yang dikonsumsi ternak kuda, dari aspek pencernaan kuda pacu termasuk hewan herbivora nonruminan, yang memiliki sistem pencernaan yang cukup sederhana atau tidak sempurna dibandingkan dengan 
ternak ruminansia. Ternak kuda mempunyai lambung yang relatif kecil tetapi efisien dalam pemanfaatan bijibijian, keunggulan lain pada ternak kuda yaitu mempunyai sekum dan kolon yang besar dalam pemanfaatan pakan kasar (roughage) dibantu oleh mikroorganisme untuk produksi energi dan vitamin B, sehingga fungsinya mirip rumen pada ternak sapi. Berdasarkan uraian di atas maka dilakukan penelitian untuk menguji kecernaan pakan, karena tinggi rendahnya kecernaan bahan pakan memberikan arti seberapa besar bahan pakan itu mengandung zat-zat makanan yang dapat dicerna.

\section{MATERI DAN METODE PENELTIAN}

Penelitian ini telah dilaksanakan dilokasi peternak anak kuda pacu Desa. Tompaso Kecamatan Tompaso dari bulan Januari - Februari 2018.

Alat- alat yang digunakan yaitu timbangan, kantong plastik dan alat tulis menulis sedangkan bahan-bahan yang digunakan yaitu jenis-jenis bahan pakan hijauan dan konsentrat sesuai dengan yang diberikan oleh peternak kuda pacu. Pakan hijauan yang diberikan adalah rumput lapang dan tebon jagung, pakan konsentrat yang diberikan terdiri dari pakan lokal antar lain; kacang hijau (vigna radiata), jagung (zea mays l), kedelai (Glycine max) dan gabah, untuk pakan impor yaitu Oats (Avesia sativa) dan Sustaina. Data hasil analisa susunan bahan pakan dapat dilihat pada Tabel 1. Komposisi zat makanan dari ransum penelitian dapat dilihat pada Tabel 2. Ternak yang digunakan adalah 20 ekor anak kuda pacu umur 13 - 24 bulan dengan kisaran bobot 100 - 150 kg. Anak kuda pacu di beri pakan hijauan tebon jagung dan rumput lapang dan konsentrat pakan lokal dan pakan impor. Data yang di kumpulkan yaitu jumlah pakan hijauan dan konsentrat yang diberikan serta jumlah feses yang didefikasi selanjutnya diambil sebanyak 300 gram sampel feses yang terdiri dari 10 sampel pakan lokal dan 10 sampel pakan impor.

Kandang yang digunakan adalah kandang individual (individual pen) yang terbuat dari dinding beton dan lantai beton sebanyak 20 unit dengan ukuran $4 \mathrm{~m} \mathrm{x} 4$ m x $4 \mathrm{~m}$ dengan lebar pintu $80 \mathrm{~cm}$. Lantai kandang diberi alas sekam padi dengan tebal antara 15-20 cm, dilengkapi dengan tempat makan yang terbuat dari beton 
Tabel 1. Kandungan Nutrisi Bahan Pakan Lokal, Pakan Impor dan Hijauan Pakan Ternak

\begin{tabular}{|c|c|c|c|c|c|c|c|}
\hline \multicolumn{8}{|l|}{$\begin{array}{l}\text { Jenis Pakan } \\
\text { Lokal }\end{array}$} \\
\hline & $\begin{array}{l}\text { BK } \\
(\%)\end{array}$ & $\begin{array}{l}\text { Energi } \\
\text { (Mkal) }\end{array}$ & $\begin{array}{c}\text { Protein } \\
(\%)\end{array}$ & $\begin{array}{c}\text { Lemak } \\
(\%)\end{array}$ & SK (\%) & CA (\%) & $\mathbf{P}(\%)$ \\
\hline Jagung & 87.9 & 3.67 & 10.4 & 4.1 & 2.5 & 0.1 & 2.56 \\
\hline K. Hijauan & 90.0 & 3.51 & 22.2 & 1.2 & 5.0 & 1.25 & 3.2 \\
\hline Kedelai & 91.0 & 4.42 & 35.9 & 18.1 & 8.0 & 2.27 & 3.85 \\
\hline Gabah & 86.8 & 3.52 & 8.4 & 1.8 & 9.7 & 0.12 & 2.9 \\
\hline \multicolumn{8}{|l|}{$\begin{array}{l}\text { Jenis Pakan } \\
\text { Impor }\end{array}$} \\
\hline Oats & 90.38 & 3.59 & 8.67 & 6.94 & 7.75 & 0.07 & 0.18 \\
\hline Sustaina & 89.00 & 1.72 & 13.2 & 6.83 & 9.04 & 0.48 & 0.19 \\
\hline \multicolumn{8}{|l|}{ Hijauan } \\
\hline Rumput Lapang & 87.46 & 3.6 & 8.33 & 1.65 & 34.64 & 0.67 & 0.44 \\
\hline Tebon Jagung & 89.5 & 3.58 & 6.05 & 1.3 & 36.15 & 0.46 & 0.30 \\
\hline
\end{tabular}

Sumber : Hasil Analisis Laboratorium Baristand Industri Manado ( Pongoh et al. 2015)

Tabel 2. Komposisi Zat Makanan Dari Pakan Lokal Dan Pakan Impor

\begin{tabular}{|c|c|c|c|c|c|c|c|}
\hline $\begin{array}{l}\text { Pakan } \\
\text { Konsentrat }\end{array}$ & & & & & & & \\
\hline & $\begin{array}{l}\text { BK* } \\
(\%)\end{array}$ & $\begin{array}{c}\text { Energi } \\
*(\text { Mkal })\end{array}$ & $\begin{array}{c}\text { Protein } \\
*(\%)\end{array}$ & $\begin{array}{c}\text { Lemak** } \\
(\%)\end{array}$ & SK $^{* *}(\%)$ & $\begin{array}{c}\text { CA** } \\
(\%)\end{array}$ & $\begin{array}{l}\text { P** } \\
(\%)\end{array}$ \\
\hline Pakan Lokal & 87.47 & 3.66 & 9.63 & 4.37 & 3.07 & 1.15 & 0.60 \\
\hline Pakan Impor & 91.24 & 3.91 & 11.037 & 8.00 & 10.00 & 0.70 & 0.40 \\
\hline Hijauan & & & & & & & \\
\hline $\begin{array}{l}\text { Rumput } \\
\text { Lapang }\end{array}$ & 87.76 & 3.16 & 9.63 & 1.65 & 34.64 & 0.67 & 0.44 \\
\hline $\begin{array}{l}\text { Tebon } \\
\text { Jagung }\end{array}$ & 92.43 & 3.76 & 6.13 & 1.3 & 36.15 & 0.46 & 0.3 \\
\hline $\begin{array}{c}\text { Rataan } \\
\text { Hijauan }\end{array}$ & 88.46 & 3.56 & 8.26 & 34.29 & 1.64 & 0.64 & 0.42 \\
\hline Sumber: *) $\mathrm{H}$ & at Per & $\begin{array}{l}\text { an Bogor } \\
\text { kal dan im }\end{array}$ & $\begin{array}{l}\text { Ilmu d } \\
\text { Iasil Ana } \\
\text { llung, } 201 \\
\text { pada tab }\end{array}$ & Teknologi & $\begin{array}{l}\text { man Instit } \\
\text { m Ilmu da } \\
\text { rdasarkan }\end{array}$ & $\begin{array}{l}\text { Pertani } \\
\text { Teknolc } \\
\text { Tdungar }\end{array}$ & $\begin{array}{l}\text { ogor } \\
\text { akan } \\
\text { rient }\end{array}$ \\
\hline
\end{tabular}

Ternak yang digunakan adalah 20 ekor anak kuda pacu umur 13 - 24 bulan dengan kisaran bobot 100 - $150 \mathrm{~kg}$. Anak kuda pacu di beri pakan hijauan tebon jagung dan rumput lapang dan konsentrat pakan lokal dan pakan impor. Data yang di kumpulkan yaitu jumlah pakan hijauan dan konsentrat yang diberikan serta jumlah feses yang didefikasi selanjutnya diambil sebanyak 300 gram sampel feses yang terdiri dari 10 sampel pakan lokal dan 10 
sampel pakan impor. Kandang yang digunakan adalah kandang individual (individual pen) yang terbuat dari dinding beton dan lantai beton sebanyak 20 unit dengan ukuran $4 \mathrm{~m}$ x $4 \mathrm{~m} \times 4 \mathrm{~m}$ dengan lebar pintu $80 \mathrm{~cm}$. Lantai kandang diberi alas sekam padi dengan tebal antara 15-20 $\mathrm{cm}$, dilengkapi dengan tempat makan yang terbuat dari beton berukuran $70 \mathrm{~cm} \mathrm{x}$ $30 \mathrm{~cm}$ x $30 \mathrm{~cm}$ dan tempat minum yang terbuat dari beton berukuran $30 \mathrm{~cm}$ x 30 $\mathrm{cm} \times 20 \mathrm{~cm}$.

Penelitian ini menggunakan metode experimen melalui koleksi total yaitu jumlah feses yang didefikasi dan metode servey dengan teknik pengambilan data yaitu wawancara untuk pakan yang diberikan di lokasi peternakan kuda pacu. Data hasil penelitian dianalisis dengan menggunakan metode ujit ( $t$-test) two-Sample Assuming Equal Variances.

Tahap 1 Pendahuluan: 7 (tujuh) hari untuk mengetahui apakah pakan yang diberikan dapat dikonsumsi secara keseluruhan atau tidak tersisa. Pemberian pakan dilakukan 2 kali sehari yaitu pagi hari jam 09.00 dan sore hari jam 16.00 jumlah pakan yang diberikan yaitu $16 \mathrm{~kg}$ yang terdiri hijaun $10 \mathrm{~kg}$ dan konsentrat 6 $\mathrm{kg}$.

Tahap 2 Koleksi: Waktu yang di perlukan dalam periode koleksi ini adalah enam hari, periode pengambilan data dilakukan dengan metode koleksi total yaitu jumlah feses (defikasi) selama 1 x 24 jam kemudian ditimbang 200 gram dari berat feses yang dikumpulkan secara komposit. Hijauan pakan lokal dan pakan impor ditimbang terlebih dahulu sebelum diberikan kepada kuda, pengumpulan dan penampungan feses yaitu menggunakan kantong plastik, sekop, timbangan, aluminium foil. Pengambilan dan penimbangan sampel feses pagi dan sore kemudian sampel-sampel feses dikeringkan di panas matahari untuk menstabilisasi kadar air. Sampel - sampel feses tersebut sesudah kering di timbang kembali untuk mengetahui berat keringnya. Variabel yang diamati dalam penelitian ini adalah:

Kecernaan lemak kasar

$=\frac{\text { Kons lemak }- \text { lemak feses output }}{\text { kons lemak }} \times 100 \%$

Kecernaaan serat kasar

$=\frac{\text { Kons serat }- \text { serat feses output }}{\text { kons serat }} \times 100 \%$

\section{HASIL DAN PEMBAHASAN}

Hasil penelitian tentang rataan jumlah konsumsi pakan lokal dan pakan impor ditampilkan pada Tabel 3 ternyata kuda yang diberi pakan impor (konsentrat), mengkonsumsi hijauan maupun konsentrat lebih tinggi di bandingkan yang diberi 
pakan lokal. Hasil analisis ujit (t-test) twoSample Assuming Equal Variances menunjukkan adanya perbedaan yang nyata $(\mathrm{p}<0.05)$ antara konsumsi bahan kering pakan impor dibandingkan dengan pakan lokal.

\section{Kecernaan Lemak}

Tabel 4 menunjukkan rataan angka kecernaan lemak kasar untuk pakan lokal sebesar $62.19 \%$ dan pakan impor $74.38 \%$. Hasil uji t (t-test) two-Sample Assuming Equal Variances menunjukkan bahwa kecernaan lemak kasar pakan impor berbeda nyata lebih tinggi $(\mathrm{P}<0,05)$ dibandingkan dengan kecernaan lemak kasar pakan lokal. Hal ini, berarti perlakuan pakan impor memberikan respon yang tidak sama atau berbeda dibandingkan dengan perlakuan menggunakan pakan lokal. Penelitian ini tidak jauh berbeda dengan penelitian sebelumnya dari Jansen dkk (2002) yang meneliti kuda saat di trotters dengan perlakuan pakan minyak kedelai, tepung jagung dan glukosa dengan perkiraan kecernaan lemak kasar 65\%. Hasil penelitian ini ternyata perlakuan pakan impor memberi respon angka kecernaan lemak lebih tinggi, dibandingkan dengan apa yang sudah di teliti oleh Jansen dkk (2002) akan tetapi penelitian Jansen masih lebih tinggi angka kecernaan lemak dari perlakuan pakan lokal. Penelitian menggunakan perlakuan pakan impor memberi respon angka kecernaan lebih tinggi karena kandungan nutrisi dari pada pakan impor lebih baik dari pada perlakuan pakan lokal dan perlakuan pakan minyak kedelai, tepung jagung dan glukosa. Duberstein dan Johnson (2009) mengemukakan bahwa kuda dapat mentolerir level lemak yang cukup tinggi karena lemak merupakan sumber energi yang sangat baik dan merupakan energi yang mudah dicerna. Lebih lanjut dikemukakan bahwa produk pakan komersial saat ini menerapkan untuk penambahan lemak sekitar 6 sampai $12 \%$ dalam ransum kuda karena dengan menambahkan lemak dalam pakan dapat meningkatkan kepadatan energi pada kuda. Akibat dari kepadatan energi tersebut maka kebutuhan nutrisi lain harus benarbenar tersedia artinya zat-zat nutrisi lainnya seperti protein, vitamin, mineral harus ditambahkan atau ditingkatkan karena dengan penambahan lemak akan mengakibatkan konsumsi pakan kuda menurun. Hal ini dimaksudkan supaya apabila konsumsi menurun tetapi dengan meningkatnya kandugan nutrisi lainya diharapkan pakan yang diberikan dapat memenuhi kebutuhan kuda.

\section{Kecernaan Serat Kasar}


Tabel 4 menunjukkan Rataan kecernaan serat kasar untuk pakan lokal dan pakan impor adalah $61,67 \%$ dan $73.07 \%$. Hasil ujit (t-test) two-Sample Assuming Equal Variances menunjukkan bahwa kecernaan serat kasar pakan impor berbeda nyata lebih tinggi $(\mathrm{P}<0,05)$ dibandingkan dengan kecernaan serat kasar pakan lokal. Joe, (1998) yang meneliti 120 perlakuan pakan yang (berbeda dengan berbagai parameter nutrisi salah satunya serat kasar dimana hasil penelitian kecernaan serat kasar yang diperoleh berkisar 49-60\% jadi masih lebih rendah dari penelitian penggunan perlakuan pakan lokal dan impor. Hal ini
Menunjukkan bahwa tingginya angka kecernaan serat kasar karena nilai biologis pakan impor lebih baik dari pada pakan lokal, dimana kandungan nutrisi pakan oats dan sustaina lebih baik dari pada gabah, kedelai pakan lokal. Kohnke et al. (1992), mengemukakan kuda membutuhkan serat yang cukup tinggi dalam pakan karena kuda memiliki sistem pencernaan fermentatif sekum dan kolon namun karena pencernaan fermentatif yang terjadi dibagian belakang sehingga proses penyerapan tidak maksimal dimana harus dikeluarkan dalam bentuk feses yang mengandung zat-zat nutrisi masih tinggi. Kuda memiliki sifat coprophagy yaitu memakan kembali feses yang dikeluarkan.

Tabel 3. Rataan Jumlah Konsumsi Anak Kuda Pacu dalam Bahan Kering

\begin{tabular}{cccc}
\hline Uraian & Hijauan $(\mathrm{g})$ & Konsentrat $(\mathrm{g})$ & Total Konsumsi $(\mathrm{g})$ \\
\hline Pakan Lokal & 1490 & 4325 & 5816 \\
Pakan Impor & 1334 & 5078 & 6411 \\
\hline
\end{tabular}

Tabel 4. Rataan Kecernaan dari Anak Kuda Pacu yang Mengkonsumsi Pakan Lokal dan Impor

\begin{tabular}{lcc}
\hline & Pakan Lokal (\%) & Pakan Impor (\%) \\
\hline Kecernaan Lemak Kasar & $62.19^{\mathrm{a}}$ & $74.38^{\mathrm{b}}$ \\
Kecernaan Serat Kasar & $61.67^{\mathrm{a}}$ & $73.07^{\mathrm{b}}$ \\
\hline
\end{tabular}


Asupan serat dari pemberian rumput adalah penting untuk mempertahankan fungsi yang efisien pada pencernaan yang sehat akan tetapi konsumsi serat kasar pada kuda berbeda dari ternak ruminansia karena pada alat pencernaan kuda hanya memilik satu ruang lambung sedangkan pada ruminansia miliki empat ruang lambung yaitu rumen, retikulum, omasum abomasum. Usman (2013), menyatakan bahwa ruminansia miliki keistimewan pada alat pencernaanya adalah miliki rumen yang digunakan sebagai tempat fermentasi dan membantu pemecahan pakan beserat tinggi. Sistem pencernaan fermentatif pada ruminansia terjadi dibagian depan yang mendahului pencernaan enzimatik menyebabkan kemampuan mencerna serat lebih besar, namun pada kuda terjadi dibagian belakang yaitu sekum dan kolom sehingga proses penyerapan produk fermentasi volatile fetty acid (VFA) dan vitamin B dan $\mathrm{K}$ tidak berlangsung lama. Tulung (2012), menyatakan bahwa untuk kuda pacu serat kasar yang tinggi dalam pakan bukan merupakan masalah karena kuda memiliki sistem pencernaan serat pada sekum dan kolon yang cukup baik dalam mencerna serat. Pemberian pakan serat seperti hijauan sebaiknya dilakukan sedikit - sedikit dengan frekuensi 3 - 4 kali sehari, sehingga tidak terjadi gangguan metabolisem pada sistem pencernaan kuda.

\section{KESIMPULAN}

Berdasarkan hasil penelitian ini dapat disimpulkan bahwa kecernaan lemak kasar dan serat kasar pakan impor lebih baik dibandingkan dengan pakan lokal.

\section{DAFTAR PUSTAKA}

Duberstein, J.K and E.D Johnson. 2009. How to Feed a Horse: Understanding Basic Principles of Horse Nutrition. The University of Georgia and Ft. Valley State University, the U.S. Department of Agriculture and counties of the state cooperation.

Jansen, W.L., S.N Geelen, van der Kuilen J, and A.C Beynen. 2002. Dietary soyabean oil depresses the apparent digestibility of fire in trotters when substituted for an iso energetic amount of corn starch or glucose. Equine Vet J 34: 302-305.

Joe, D.P. 1998. Nutrient Digestibility In Horses Kentucky Equine Research Inc Versailles Kentucky USA.

Kohnke, J.R., F. Kelleher and P. TrevorJones. 1992. Feeding horses in australia: a guide for horse owners and managers. RIRDC Publication Journa 99

Manarisip, C.M., Y. L. R Tulung., W. B. Kaunang., dan R. A. V. Tuturong. 2017. Perbandingan nilai biologis pakan lokal dan impor pada anak kuda pacu Indonesia. Jurnal Zootek $37.1: 33-40$. 
Pongoh, V. M., B. Tulung, Y, L. R. Tulung, L.J.M. Rumokoy. 2015.Uji Karakteristik fisik dan kimia pakan lokal dan impor kuda pacu Minahasa. Jurnal Zootek . 35 No. 1 : 62-71.

Susanti, S. dan E. Marhaeniyanto. 2007. Kecernaan, retensi nitrogen dan hubungannya dengan produksi susu pada Sapi Peranakan Friesian Holstein (PFH) yang diberi Pakan Pollard dan Bekatul. Jurnal Protein 15(2) : 141-147.

Tulung, Y.L.R. 2012. Kebutuhan Energi dan Nutrien Kuda pacu Indonesia dan Aplikasi pada Formulasi Ransum Berbasis Pakan Lokal. Disertasi. Program Pascasarjana Institut Pertanian Bogor.

Usman, Y. 2013. Pemberian pakan serat sisa tanaman pertanian (jerami kacang tanah, jerami jagung, Pucuk tebu) terhadap evolusi $\mathrm{pH}, \mathrm{N}-\mathrm{NH} 3$ dan VFA di dalam rumen sapi. Jurnal Agripet 13 (2) : 53-58. 